\title{
$\mathrm{St} / \mathrm{BA}$ 를 혼입한 폴리머 시멘트 모르타르의 부착강도 및 인장강도 특성
}

\author{
유기표 · 형원길*,† \\ 전북대학교 건축공학과, *영남대학교 건축학부 \\ (2014년 6월 23일 접수, 2014년 7월 22일 수정, 2014년 8월 5일 채택)
}

\section{Bond Strength and Tensile Strength of Polymer-Modified Mortar Using Styrene and Butyl Acrylate}

\author{
Kipyo You and Wongil Hyung* ${ }^{\dagger}$ \\ Department of Architectural Engineering, Jeonbuk National University, Jeonju 561-756, Korea \\ * School of Architecture, Yeungnam University, Gyeongsan 712-749, Korea \\ (Received June 23, 2014; Revised July 22, 2014; Accepted August 5, 2014)
}

\begin{abstract}
초록: 본 연구에서는 styrene(St)와 butyl acrylate(BA)를 단량체로 폴리머를 합성하여 폴리머 필름의 인장강도를 측 정하고 폴리머 시멘트 모르타르로 제작하여 세공구조와 부착강도, 그리고 인장강도와의 상호 연관성을 파악하고자 하였다. 본 연구결과 $\mathrm{St} / \mathrm{BA}$ 폴리머 필름의 인장강도는 $\mathrm{St}$ 의 함유량이 높을수록 증가하는 것으로 나타났으며. 폴리머 시멘트 모르타르의 부착강도와 인장강도는 폴리머 필름의 인장강도가 클수록, 미세공극량이 많을수록 우수하게 나 타나고 있다.
\end{abstract}

\begin{abstract}
The objective of this study is to find the relationship between the tensile strength of the polymer film and the bond strength and tensile strength of the polymer-modified mortar using styrene (St) and butyl acrylate (BA), and porosity. In the test results, the bond strength and tensile strength of the polymer-modified mortar increased with increases in the tensile strength of polymer film and the fine pore volume.
\end{abstract}

Keywords: polymer, polymer-modified mortar, porosity, bond strength, tensile strength.

\begin{abstract}
서 론
시멘트 혼화용 폴리머는 현대 건축물에서 가장 많이 사용 되고 있는 시멘트 콘크리트의 문제점을 개선할 수 있는 신재 료로 널리 사용되고 있으며, 노후화된 건축물의 보수, 보강재 료로도 많이 사용되고 있다. 시멘트 혼화용 폴리머는 일반 시 멘트 콘크리트에 혼입하여 그 성질을 개선시키는데 목적이 있으며 강도, 부착성, 내구성 등을 개선시켜 건물의 외장재, 바닥마감재, 포장재, 장식 코팅재, 보수재 등의 용도로 많이 사용되고 있다. ${ }^{1-3}$

폴리머 시멘트 복합체의 강도 증진은 시멘트 수화물과 폴 리머 필름에 의해 결정되는 것으로 알려져 있다. 시멘트 페 이스트에는 주로 규산칼슘(calcium silicate)과 수산화칼슘 (calcium hydroxides) 수화물로 구성되어 있으며 이들의 경계 면에서 미세한 균열이 발생한다. 이런 수화물들의 경계면이 나 미세한 균열, 그리고 시멘트와 골재사이의 공간에서 폴리
\end{abstract}

${ }^{\dagger}$ To whom correspondence should be addressed.

E-mail: beda@yu.ac.kr
머 필름이 형성된다. 계면에서 형성되는 폴리머 필름은 시멘 트와 골재의 결합력을 높여주고 미세균열 내에서 형성되는 연속된 필름은 폴리머 시멘트 복합체의 강성을 높여주게 된 다. ${ }^{4}$ 폴리머 필름의 자체강도는 매우 낮지만 계면과 미세균열 에 형성된 필름으로 인해 폴리머 시멘트 복합체의 강도증진 효과를 가져 올 수 있으며, 이 때 가장 높은 효과를 기대할 수 있는 것이 부착강도와 인장강도이다. 폴리머 시멘트 경화 체의 부착강도와 인장강도는 폴리머의 종류에 따라서 다소 차이가 있기는 하지만 일반적으로 폴리머 시멘트 비가 증가 할수록 강도도 증진되는 것으로 알려져 있으며, 폴리머 시멘 트 비가 10 20\%일 때 우수한 강도특성을 갖는 것으로 알려 져 있다. ${ }^{6}$ 이처럼 폴리머 시멘트 경화체는 일반 시멘트 경화 체의 많은 단점을 보완해 주기는 하지만 사용 시 주의해야 하는 부분도 있다. 예를 들면 폴리머 시멘트 경화체의 시공 성은 보통 시멘트 경화체에 비해 월등하게 향상되지만 과다 한 공기량으로 인하여 강도저하의 원인이 될 수 있으며, 폴 리머의 혼입으로 인해 시멘트 수화반응을 억제시켜 경화시간 이 지연되는 경우도 있다. 시멘트 모르타르에 폴리머를 혼입 하면 시멘트 경화체 내의 세공구조에서는 큰 공극은 줄어들 
고 미세공극은 증가하는 효과를 얻을 수 있지만 과다한 폴리 머의 혼입은 폴리머 필름이 필요이상으로 형성되어 폴리머 시멘트 복합체의 강도를 저하시키는 요인이 될 수 있다. ${ }^{4}$ 본 연구에서는 styrene(St)과 butyl acrylate(BA)를 단량체로 폴리 머를 합성하여 폴리머 필름의 인장강도를 측정하고 폴리머 시멘트 모르타르(PCM)로 제작하여 세공구조와 부착강도, 그 리고 인장강도와의 상호 연관성을 파악하고자 하였다.

\section{실 험}

재료. 본 실험에서 사용된 시멘트는 KS L5201에 규정된 보통 포틀랜드 시멘트를 사용하였으며 화학적 성분과 물리적 성능은 Table 1, Table 2와 같다. 잔골재는 규사(size: 0.25 $0.6 \mathrm{~mm}$ )를 사용하였으며 물리적 성질은 Table 3과 같다. 시 멘트 혼화용 폴리머는 $\mathrm{St} / \mathrm{BA}$ 비를 40:60, 50:50, 그리고 $60: 40$ 으로 합성시킨 에멀젼을 사용하였으며, 그 배합은 Table 4 와 같다. 폴리머 시멘트 모르타르(이하 $\mathrm{PCM}$ )의 공기량을 조절 하기 위하여 소포제(anti-foamer)는 실리콘계 에멀젼(고형분, $30 \%$ )을 사용하였으며, 폴리머의 전 고형분(solid content)의 $0.7 \%$ 를 첨가하였다.

폴리머의 제조. 본 실험에서 사용된 폴리머를 제조하기 위 하여 폴리머 합성 방법 중 하나인 유화(에멀젼)중합법을 이

Table 1. Chemical Compositions of Ordinary Portland Cement

\begin{tabular}{cccccccc}
\hline $\mathrm{SiO}_{2}$ & $\mathrm{Al}_{2} \mathrm{O}_{3}$ & $\mathrm{CaO}$ & $\mathrm{MgO}$ & $\mathrm{SO}_{3}$ & $\mathrm{~K}_{2} \mathrm{O}$ & $\mathrm{Na}_{2} \mathrm{O}$ & $\mathrm{Fe}_{2} \mathrm{O}_{3}$ \\
\hline 21.09 & 4.84 & 63.85 & 3.32 & 3.09 & 1.13 & 0.29 & 2.39 \\
\hline
\end{tabular}

Table 2. Physical Properties of Ordinary Portland Cement

\begin{tabular}{ccccccc}
\hline Specific & \multirow{2}{*}{$\begin{array}{c}\text { Blainess } \\
\text { gravity }\end{array}$} & \multicolumn{3}{c}{ Secting time } & \multicolumn{4}{c}{$\begin{array}{c}\text { Compressive strength } \\
\text { of mortar }(\mathrm{MPa})\end{array}$} \\
\cline { 3 - 7 }$\left(20^{\circ} \mathrm{C}\right)$ & $\begin{array}{c}\text { surface } \\
\left(\mathrm{cm}^{2} / \mathrm{g}\right)\end{array}$ & $\begin{array}{c}\text { Initial set } \\
(\mathrm{min})\end{array}$ & $\begin{array}{c}\text { Final set } \\
(\mathrm{h})\end{array}$ & $3 \mathrm{~d}$ & $7 \mathrm{~d}$ & $28 \mathrm{~d}$ \\
\hline 3.15 & 3300 & 240 & $7: 00$ & 20 & 23 & 39 \\
\hline
\end{tabular}

Table 3. Properties of Fine Aggregate

\begin{tabular}{ccccc}
\hline $\begin{array}{c}\text { Max. size } \\
(\mathrm{mm})\end{array}$ & $\begin{array}{c}\text { Unit weight } \\
(\mathrm{kg} / \mathrm{l})\end{array}$ & $\begin{array}{c}\text { Specific } \\
\text { gravity } \\
\left(20^{\circ} \mathrm{C}\right)\end{array}$ & $\begin{array}{c}\text { Water } \\
\text { absorption } \\
(\%)\end{array}$ & $\begin{array}{c}\text { Solid volume } \\
\text { percentage } \\
(\%)\end{array}$ \\
\hline$<1.2$ & 1.5 & 2.62 & 0.40 & 58.1 \\
\hline
\end{tabular}

Table 5. Properties of Polymer Dispersions for Cement Modifier

\begin{tabular}{cccccc}
\hline $\begin{array}{c}\text { Type of } \\
\text { polymer }\end{array}$ & $\begin{array}{c}\text { Monomer ratio } \\
\text { (St/BA), } \\
\text { by weight }\end{array}$ & $\begin{array}{c}\text { Specific } \\
\text { gravity } \\
\left(20^{\circ} \mathrm{C}\right)\end{array}$ & $\begin{array}{c}\mathrm{pH} \\
\left(20^{\circ} \mathrm{C}\right)\end{array}$ & $\begin{array}{c}\text { Total } \\
\text { solids } \\
(\%)\end{array}$ & $\begin{array}{c}T_{\mathrm{g}} \\
\left({ }^{\circ} \mathrm{C}\right)\end{array}$ \\
\hline SB40* & $40: 60$ & 1.04 & 6.0 & 48.2 & -6.7 \\
SB50 & $50: 50$ & 1.04 & 6.0 & 46.7 & 5.3 \\
SB60 & $60: 40$ & 1.04 & 7.0 & 47.2 & 15.9 \\
\hline
\end{tabular}

*Styrene content of $40 \%$

용하였으며, St/BA의 단량체 비를 변화시키고 목표 고형분량 이 $50 \%$ 인 에멀젼을 만들었다. 먼저 유화제와 개시제를 증류 수에 용해시킨 후 반응조에 넣고 반응조 안의 임펠러를 회전 시키면서 온도를 $80^{\circ} \mathrm{C}$ 까지 상승시킨 후, 단량체를 초당 한 방울씩 첨가하면서 12 24시간 동안 지속적으로 반응시켜 폴 리머를 제조하였다. 반응이 이루어지는 시간 동안 반응조의 온도는 $80^{\circ} \mathrm{C}$ 를 계속 유지하였다. 이 때 styrene(St)과 butyl acrylate(BA)는 일본 Junsei Chemical사의 1급 시약을 사용하 였으며, 점성을 높이기 위해서 methyl methacrylate (MMA)를 사용하였다. 유화제는 미국 Aldrich사의 octoxynol계 TritonX100(TX100)과 일본 TSC사의 sodium dodecyl sulfonate(SDS) 의 두 가지 종류를 같은 비율로 혼합하여 사용하였다. 개시 제는 일본 Junsei Chemical사의 potassium peroxodisulfate (KPS)와 sodium hydrogen carbonate $\left(\mathrm{NaHCO}_{3}\right)$ 를 사용하였으 며 물은 1 차 증류수를 반응 매질로 사용하였다. 단량체 비에 따른 폴리머 에멀젼의 밀도는 KS A 0601 [액체 밀도 측정 방법]에 준하여 측정하였으며, $\mathrm{pH}$ 는 리트머스 시험지를 이용 하여 측정하였다. 또 고형분량을 측정하기 위하여 $30 \mathrm{~g}$ 의 라 텍스를 유리접시에 담아 $40^{\circ} \mathrm{C}$ 의 건조로에서 48 시간 동안 건 조시킨 후 질량변화를 통하여 측정하였으며, 그 성질은 Table 5 와 같다.

폴리머의 입도분석 및 유리전이온도 측정. 입도분석은 레 이져 산란 입도분석기를 이용하여 측정하였다. 유리전이온도 $\left(T_{\mathrm{g}}\right)$ 는 건조된 필름의 일부를 채취하여 $\mathrm{DSC}($ differential scannig calorimeter)를 이용하여 $10^{\circ} \mathrm{C} / \mathrm{min}$ 로 $-100 \sim 150^{\circ} \mathrm{C}$ 범 위까지 스캔하여 측정하였다.

폴리머 필름 인장강도 측정. 폴리머 필름의 인장강도를 측 정하기 위하여 폴리머 라텍스를 $40^{\circ} \mathrm{C}$ 의 건조로에서 48 시간 동안 건조시켜 시편을 제작하고 $\mathrm{KS} \mathrm{M} \mathrm{3381유리섬유} \mathrm{강화플}$

Table 4. Composition for Polymerization

\begin{tabular}{|c|c|c|c|c|c|c|c|}
\hline \multirow{2}{*}{ Type of polymer } & \multirow{2}{*}{$\begin{array}{l}\text { St:BA } \\
(\%)\end{array}$} & \multirow{2}{*}{$\begin{array}{l}\text { MAA } \\
(\%)\end{array}$} & \multicolumn{2}{|c|}{ Initiator/Monomer (\%) } & \multicolumn{2}{|c|}{ Emulsifier/Monomer (\%) } & \multirow{2}{*}{$\begin{array}{c}\text { Aim of } \\
\text { solid content (\%) }\end{array}$} \\
\hline & & & KPS & $\mathrm{NaHCO}_{3}$ & TX100 & SDS & \\
\hline SB40 & $40: 60$ & 2.0 & 0.3 & 0.4 & 3.0 & 3.0 & 50 \\
\hline SB50 & $50: 50$ & 2.0 & 0.3 & 0.4 & 3.0 & 3.0 & 50 \\
\hline SB60 & $60: 40$ & 2.0 & 0.3 & 0.4 & 3.0 & 3.0 & 50 \\
\hline
\end{tabular}


Table 6. Mix Proportions of St/BA-modified Mortars

\begin{tabular}{|c|c|c|c|c|c|}
\hline Type of mortar & $\begin{array}{l}\text { Cememt: Sand, } \\
\text { by weight }\end{array}$ & $\begin{array}{l}\text { Polymer-cement ratio } \\
\text { (\%) }\end{array}$ & $\begin{array}{c}\text { Water-cement ratio } \\
(\%)\end{array}$ & Air content $(\%)$ & Flow (mm) \\
\hline Unmodified & $1: 3$ & 0 & 67 & 3.6 & 167 \\
\hline \multirow{4}{*}{ SB4-modified } & \multirow{4}{*}{$1: 3$} & 5 & 62 & 8.4 & 171 \\
\hline & & 10 & 54 & 9.1 & 168 \\
\hline & & 15 & 50 & 11.5 & 172 \\
\hline & & 20 & 46 & 13.2 & 171 \\
\hline \multirow{4}{*}{ SB5-modified } & \multirow{4}{*}{$1: 3$} & 5 & 59 & 7.9 & 169 \\
\hline & & 10 & 53 & 10.8 & 170 \\
\hline & & 15 & 48 & 12.4 & 168 \\
\hline & & 20 & 45 & 12.9 & 172 \\
\hline \multirow{4}{*}{ SB6-modified } & \multirow{4}{*}{$1: 3$} & 5 & 64 & 9.6 & 175 \\
\hline & & 10 & 58 & 12.0 & 170 \\
\hline & & 15 & 53 & 14.0 & 169 \\
\hline & & 20 & 50 & 15.3 & 168 \\
\hline
\end{tabular}

라스틱의 인장 시험 방법에 따라 시험을 실시하였다.

$\mathrm{St} / \mathrm{BA}$ 를 혼입한 PCM 제작. 폴리머 시멘트 모르타르는 $\mathrm{KS} \mathrm{F} 2476$ 「실험실에서 폴리머 시멘트 모르타르를 만드는 방법 $\lrcorner$ 에 따라 시멘트 : 잔골재 $=1: 3$ (질량비), 폴리머 시멘트 비 $\left(\mathrm{P} / \mathrm{C}\right.$; polymer-cement ratio)를 $0,5,10,15$ 및 $20^{\circ} \mathrm{C}$ 로 하고, 시멘트 혼화용 폴리머의 고형분에 대해 소포제를 $0.7 \%$ 로 첨 가하여, $40 \times 40 \times 160 \mathrm{~mm}$ 의 몰드로 모든 공시체를 성형한 후, 2 일간 습윤양생 $(20,80 \%$ R.H.)을 실시하고, 5 일간 수중양생 $\left(20{ }^{\circ} \mathrm{C}\right)$, 그리고 21 일간 기중양생 $\left(20^{\circ} \mathrm{C}, 50 \%\right.$ R.H. $)$ 을 실시하 여 공시체를 제작하였다. 이 때의 물 시멘트 비는 플로우가 $170 \pm 5 \mathrm{~mm}$ 의 범위가 되도록 결정하였다. 배합표는 Table 6과 같다.

$\mathrm{PCM}$ 의 부착강도 측정. $\mathrm{PCM}$ 의 부착강도를 측정하기 위 하여 먼저 피착제를 $300 \times 300 \times 60 \mathrm{~mm}$ 의 크기로 제작하여 $\mathrm{KS}$ $\mathrm{L} 6003$ 에서 규정하는 150 번 연마지를 사용해서 성형 시에 밑 면을 충분히 연마한 후, KS F 4716「시멘트계 바탕 바름재」 에 준하여 $40 \times 40 \times 10 \mathrm{~mm}$ 의 크기로 시험체를 피착체에 제작 하였다. 부착시험을 하기 위한 양생조건은 PCM의 양생방법 과 동일하게 2 일간 습윤양생 $(20,80 \%$ R.H)을 실시하고, 5 일 간 수중양생 $\left(20^{\circ} \mathrm{C}\right)$, 그리고 21 일간 기중양생 $\left(20^{\circ} \mathrm{C}, 50 \% \mathrm{R} . \mathrm{H}\right.$. $)$ 을 실시하여 부착강도를 측정하였다.

$\mathrm{PCM}$ 의 인장강도 측정. 폴리머 시멘트 모르타르의 인장강 도 시험은 KS L 5104 「수경성 시멘트 모르타르의 인장강 도 시험방법」에 의해 실시하였으며, 인장강도 시험용 공시체 는 Briquette형 몰드를 사용하여 제작하였다.

$\mathrm{PCM}$ 의 세공구조 측정. 세공구조 측정용 시편은 치수 $40 \times 40 \times 160 \mathrm{~mm}$ 의 공시체 내부에서 시료를 채취하여 아세톤 으로 세정한 후 D-dry 처리를 하여 준비하였으며, 수은 압입
식 포로시메타를 이용하여 세공용적을 측정하였다.

\section{결과 및 토론}

폴리머 에멀젼의 입도분석. Figure 1은 $\mathrm{St} / \mathrm{BA}$ 계 폴리머 에 멀젼의 입도분포를 나타낸 그래프이다. SB40 폴리머 에멀젼 의 평균입자의 크기는 $0.28 \mu \mathrm{m}$, 입도의 범위는 $0.83 \mu \mathrm{m}$ 로 나 타났으며 SB50 폴리머 에멀젼은 평균입자의 크기가 $0.25 \mu \mathrm{m}$, 범위는 $0.81 \mu \mathrm{m}$ 였다. 또 $\mathrm{SB} 70$ 폴리머 에멀젼의 경우에는

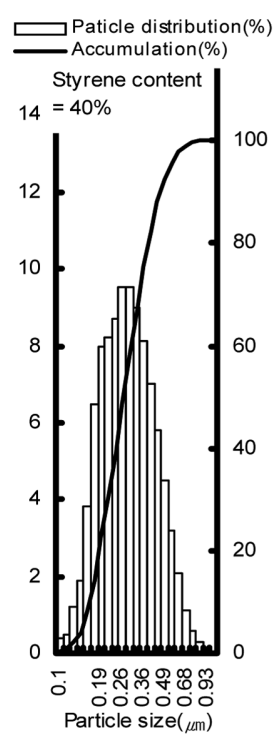

(a) SB40

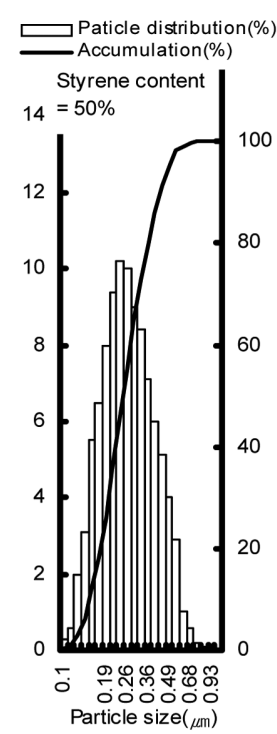

(b) SB50

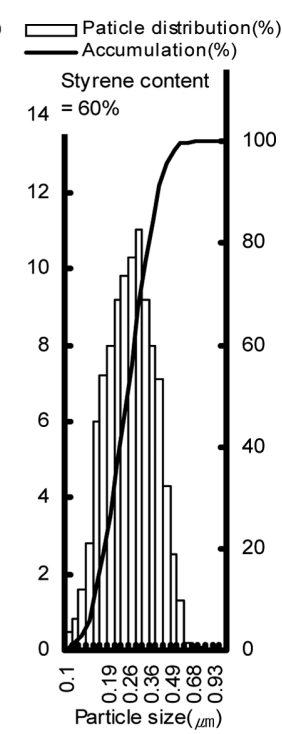

(c) SB60
Figure 1. Pore volume of St/BA-modified mortars. ${ }^{2}$ 


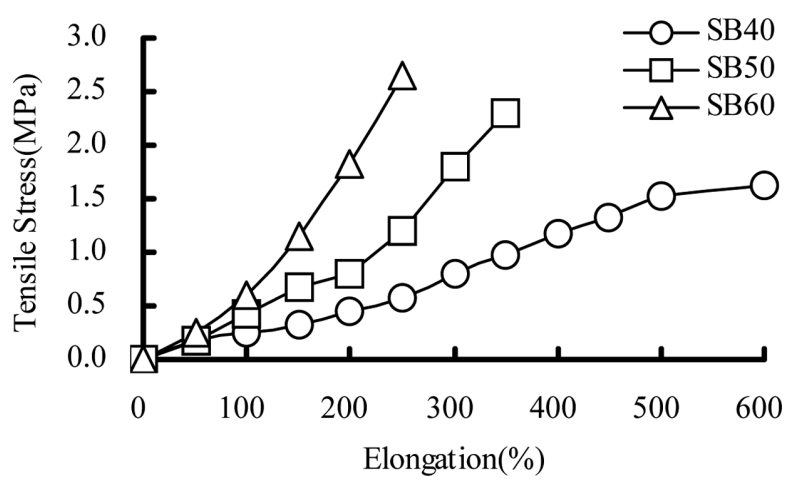

Figure 2. Glass transition temperature of polymer emulsion.

$0.17 \mu \mathrm{m}$ 의 평균크기와 $0.68 \mu \mathrm{m}$ 의 범위를 나타내고 있어 $\mathrm{St}$ 의 함유량이 증가할수록 입자의 평균크기와 분포범위가 작은 것 으로 나타났다.

폴리머 필름의 인장강도. Figure 2 는 폴리머 필름의 신장 률이 높은 경우에는 강도가 낮게 나타나고 있으며, $\mathrm{St}$ 의 함유 량이 증가할수록 인장강도는 증가하고 신장률은 낮아지는 것 을 알 수 있다. 폴리머 필름은 유리전이온도가 높을수록 신 장률은 낮고 인장강도는 높은 것으로 나타났다. 또한 St/BA 의 단량체 비가 증가할수록 유리전이온도가 높아지고 있어 인장강도 증진을 위해서는 $\mathrm{St}$ 의 함유율이 높을수록 유리할 것으로 사료된다.

$\mathrm{PCM}$ 의 물 시멘트 비. Figure 3 은 $\mathrm{St} / \mathrm{BA}$ 혼입 $\mathrm{PCM}$ 의 물 시멘트 비를 나타낸 그래프이다. $\mathrm{PCM}$ 의 물 시멘트 비는 플 로우를 고정하지 않을 경우에는 폴리머 시멘트 비가 증가할 수록 플로우 값도 증가되지만 현장에서 사용할 경우에는 시 공성이 적합하지 않고 높은 물 시멘트 비와 공기량의 증가로 인해 강도와 내구성 저하의 원인이 될 수 있다. 따라서 본 실 험에서는 플로우를 현장 시공성의 기준으로 $170 \pm 5$ 를 기준으 로 고정하여 물 시멘트 비를 결정하였다. 전체적으로 폴리머 시멘트 비가 증가할수록 물 시멘트 비가 감소하는 경향을 보 이고 있어 단량체의 변화보다는 폴리머 시멘트 비에 따른 영 향이 큰 것으로 나타났다.

PCM의 공기량. 폴리머에 함유되어 있는 유화제는 비빔 시 연행공기(entrained air)를 발생하게 된다. 이 때 발생하는 연 행공기는 동결융해에 대한 저항성을 증가시켜주지만 과다한 연행공기의 발생은 오히려 강도와 내구성을 저하시킬 수 있 다. ${ }^{4}$ Figure 4 는 St/BA 혼입 $\mathrm{PCM}$ 의 공기량을 나타낸 그래프 이다. $\mathrm{St} / \mathrm{BA} \mathrm{PCM}$ 의 경우에도 폴리머 시멘트 비가 증가할수 록 공기량이 증가하는 경향을 나타내고 있으며, $\mathrm{St} / \mathrm{BA}$ 의 단 량체 비가 증가할수록 공기량이 증가하는 것으로 나타났다. 또 $\mathrm{PCM}$ 는 폴리머 시멘트 비가 $15 \%$ 와 $20 \%$ 일 때 높은 공기 량을 나타내고 있다.

$\mathrm{PCM}$ 의 부착강도 및 인장강도. Figure 5 는 $\mathrm{St} / \mathrm{BA}$ 혼입 $\mathrm{PCM}$ 의 부착강도를 나타낸 그래프이다. $\mathrm{St} / \mathrm{BA} \mathrm{PCM}$ 의 부착

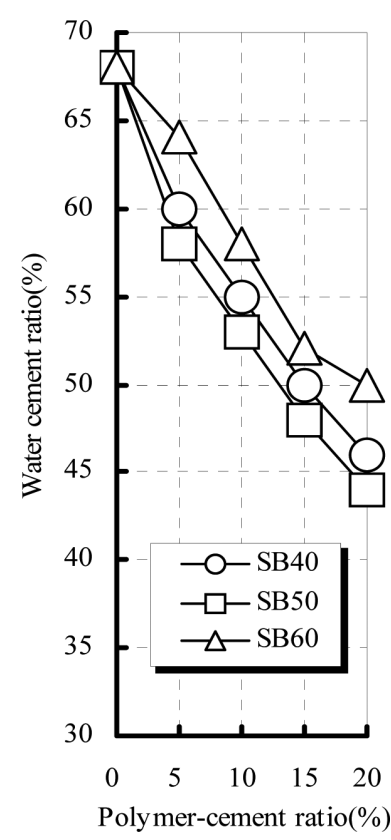

Figure 3. Water-cement ratio.
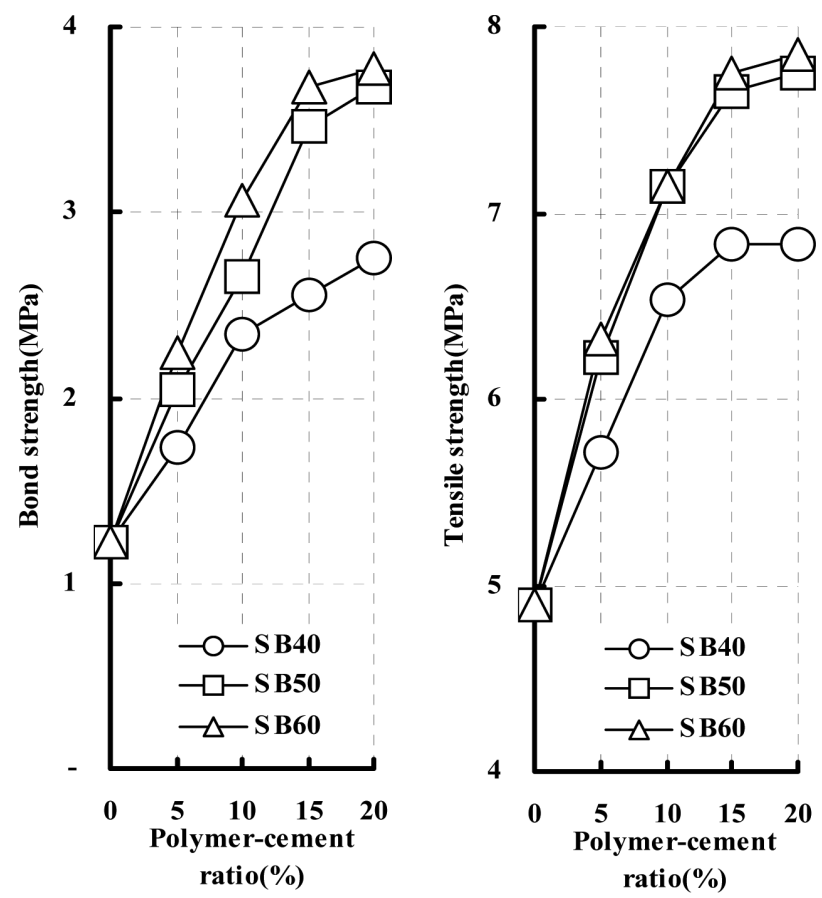

Figure 5. Bond strength.

강도는 $\mathrm{St} / \mathrm{BA}$ 의 단량체 비가 높고 폴리머 시멘트 비가 증가 할수록 높게 나타나고 있으며 보통 시멘트 모르타르에 비해 최고 3 배 정도의 증진효과가 있었다. 또한 폴리머 필름의 인 장강도가 높게 나타난 $\mathrm{SB} 50$ 과 $\mathrm{SB} 60$ 에서 우수한 부착성능을 나타내고 있는 것을 알 수 있다. 이것은 $\mathrm{PCM}$ 의 인장강도 특 성에서도 비슷한 경향을 나타내고 있다. 
Figure 6은 $\mathrm{PCM}$ 의 인장강도를 나타낸 것으로 St의 함유율 이 $50 \%$ 와 $60 \%$ 일 때 높은 인장강도 특성을 보이고 있다. 또 폴리머 혼입률이 $15 \%$ 와 $20 \%$ 일 때 인장강도가 높게 나타나 고 있어 폴리머 필름 형성률이 높을수록 $\mathrm{PCM}$ 의 인장강도도 높게 나타났다.

$\mathrm{PCM}$ 의 세공구조. 공극률(porosity)과 세공구조(pore structure)는 폴리머 시멘트 모르타르의 물리적 특성뿐 아니라 내구성에도 많은 영향을 미친다. 폴리머 시멘트 모르타르의 세공구조는 폴리머의 종류와 폴리머 시멘트 비에 따라 달라 지며, 일반적으로 세공의 크기는 $0.2 \mu \mathrm{m}$ 보다 작게 나타나고 있으며, 보통 시멘트 모르타르에 비하여 $75 \mathrm{~nm}$ 이하의 미세 공극들이 많이 분포하고 폴리머 시멘트 비가 높을수록 전 세 공용적이 적게 나타나고 있다. ${ }^{6}$ 시멘트의 수화과정에서 물이 남아 있는 부분은 공극으로 시멘트 경화체에 남아있게 되며, 이 때 수화물에 남아있는 공극을 모세관 공극(capillary pore) 이라 하고, 수화생성물이 된 시멘트 젤 자체의 내부에 포함 되어 있는 젤 입자의 공극을 젤 공극(gel pore)라고 한다. 수 화 콘크리트는 $\mathrm{C}_{3} \mathrm{~S}$ 페이스트 중 고체부분의 $60 \sim 70 \%$ 를 C-S$\mathrm{H}$ 젤이 차지하고 있고 수산화칼슘이 20 30\%를 차지하고 있 다. C-S-H 젤의 구조는 1.2 3.2 nm의 공극을 inter-crystallite pore로 정의하고 $3.2 \sim 200 \mathrm{~nm}$ 의 공극을 젤 입자간 공극이라 고 하며 젤 공극과 모세관 공극이 같이 존재하게 된다. 일반 적으로 시멘트 모르타르의 일정의 압축강도가 발현되기 위한 세공경 분포의 범위는 $50 \mathrm{~nm} 2 \mu \mathrm{m}$ 사이에 많이 존재하는 것 으로 알려져 있다. 보통 시멘트 모르타르에 폴리머를 혼입하 게 되면 젤 공극과 모세관 공극, 수화물과 골재 사이, 그리고 이들의 미세균열 속으로 폴리머 입자들이 분산되어 큰 공극 을 채우면서 필름을 형성하게 된다. 이렇게 큰 공극들 속에 폴리머 필름이 형성됨으로써 많은 미세공극이 많이 분포하게 되어 강도와 내구성에 영향을 미치게 되는 것이다. Ohama는 일련의 실험들을 통하여 큰 공극과 미세공극의 범위를 $75 \mathrm{~nm}$ 를 기준으로 설정하였다., ${ }^{46}$

Figure 7은 St/BA PCM의 전 세공용적과 세공경 분포를 나 타낸 그래프이다. St/BA PCM의 전 세공용적은 보통 시멘트 모르타르에 비해 전체적으로 작게 나타나고 있으며, 폴리머 시멘트 비가 증가하면서 미세공극이 증가하는 것으로 나타나 고 있다. SB40 PCM은 보통 시멘트 모르타르와 비슷한 세공 구조를 나타내고 있으며 폴리머 시멘트 비가 증가할수록 미 세공극도 증가하는 경향을 나타내고 있다. SB50 PCM의 세 공구조를 보면 폴리머 시멘트 비가 $5,10 \%$ 일 때를 제외하고 미세공극량이 증가하는 것으로 나타나고 있으며, SB60 PCM 의 경우에도 전 세공용적은 감소하고 미세공극량은 증가하는 것으로 나타났다. St/BA의 단량체 비 배합조건에 따라서는 $\mathrm{St}$ 의 비율이 증가할수록, 폴리머 시멘트 비가 $15 \%$ 와 $20 \%$ 일 때는 전 세공용적은 감소하고 미세공극량은 증가하는 것으로 나타나고 있어 $\mathrm{St} / \mathrm{BA}$ 의 단량체 비가 증가할수록 강도특성이

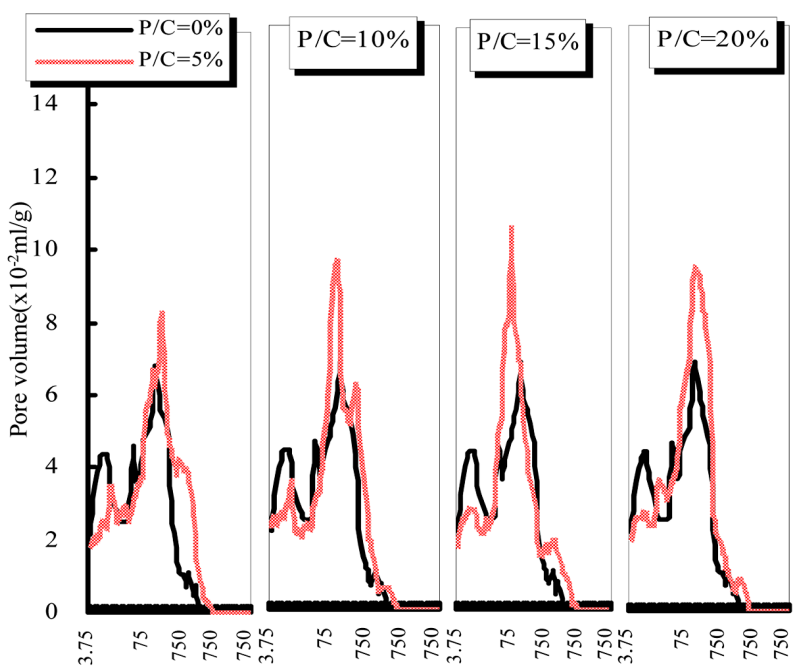

(a)

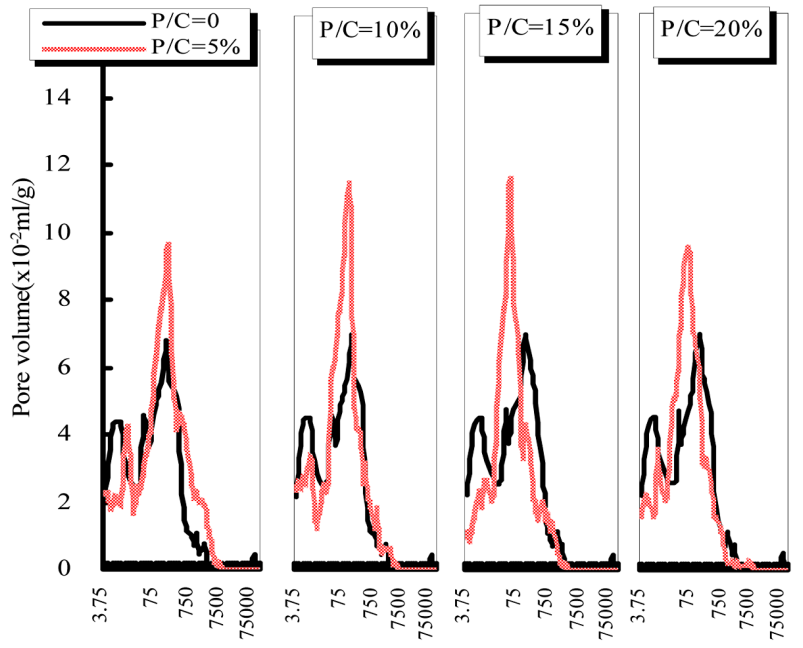

(b)

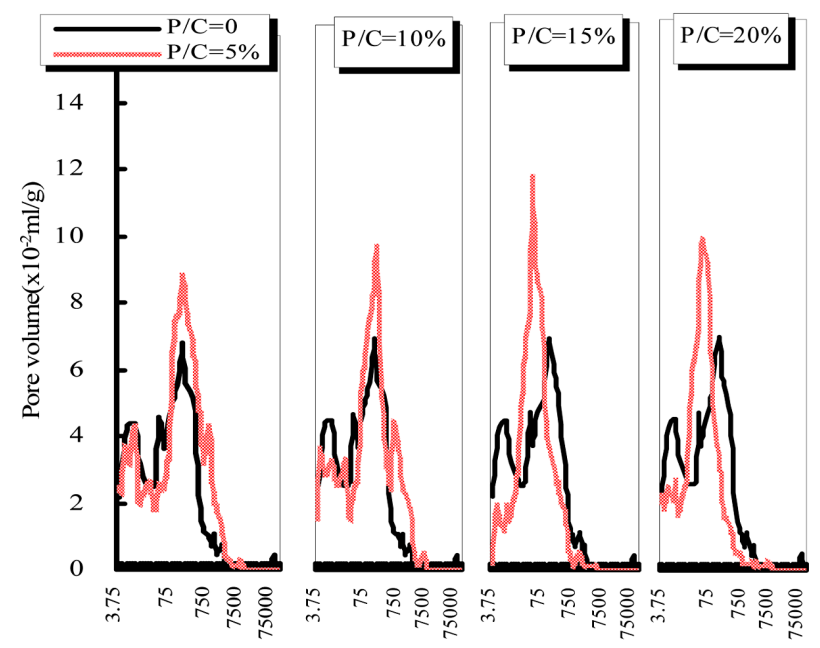

(c)

Figure 7. Pore size distribution of PCM using St/BA: (a) polymermodified mortar using SB40; (b) polymer-modified mortar using SB50; (c) polymer-modified mortar using SB60. 
증진될 것으로 판단된다. $\mathrm{SB} 50$ 과 $\mathrm{SB} 60 \mathrm{PCM}$ 에서 폴리머 시 멘트 비가 $15 \%$ 와 $20 \%$ 일 때 미세공극량의 증가로 $\mathrm{PCM}$ 의 부 착강도와 인장강도 증진효과를 기대할 수 있을 것으로 사료 된다.

$\mathrm{PCM}$ 의 세공구조에 따른 강도특성. Figures 8 10은 폴리 머 시멘트 모르타르의 세공구조에 따른 부착강도와 인장강도 를 나타낸 그래프이다. 보통 시멘트 모르타르에 폴리머를 혼 입하게 되면 젤 공극과 모세관 공극, 수화물과 골재 사이, 그 리고 이들의 미세균열 속으로 폴리머 입자들이 분산되어 큰 공극을 채우면서 필름을 형성하게 된다. 이렇게 큰 공극들 속

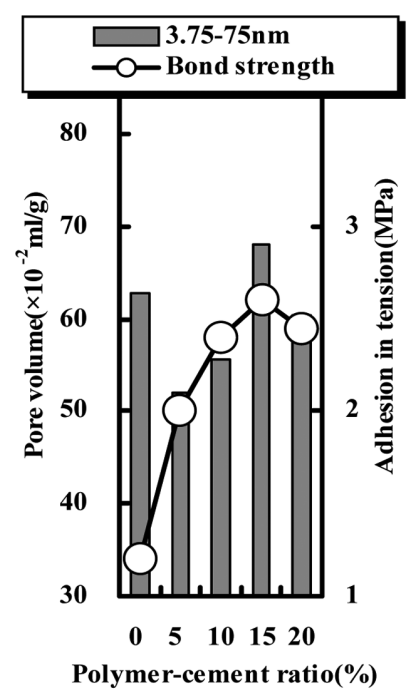

(a) Bond strength

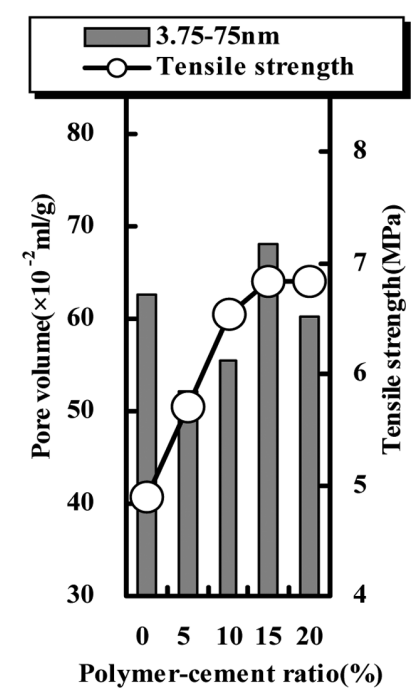

(b) Tensile strength
Figure 8. Polymer-modified mortar using SB40.

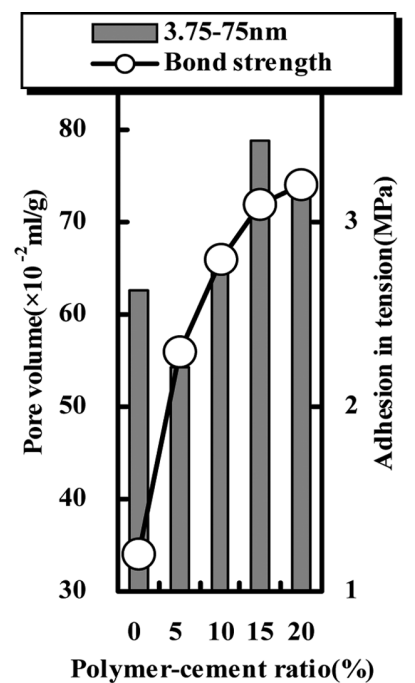

(a) Bond strength

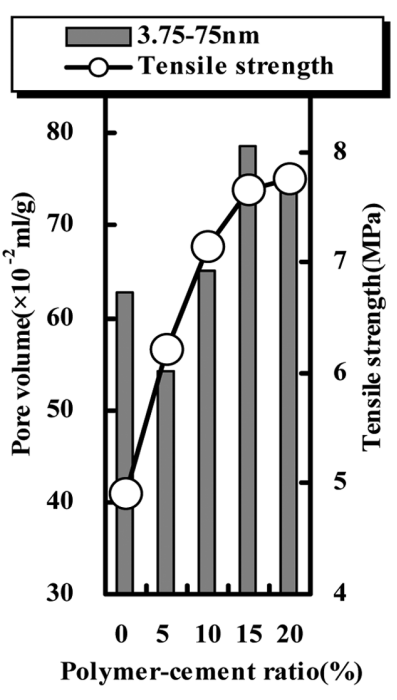

(b) Tensile strength
Figure 9. Polymer-modified mortar using SB50.

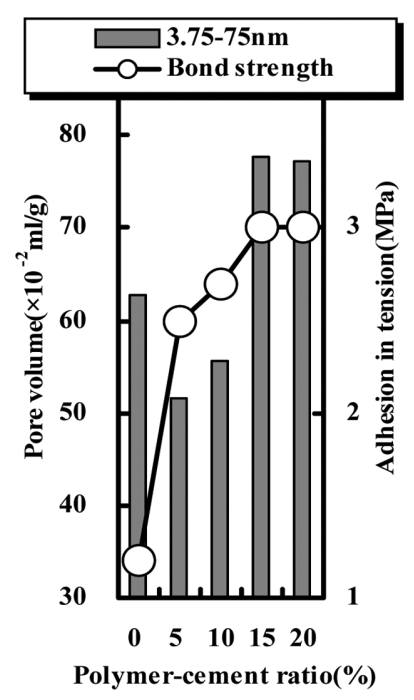

(a) Bond strength

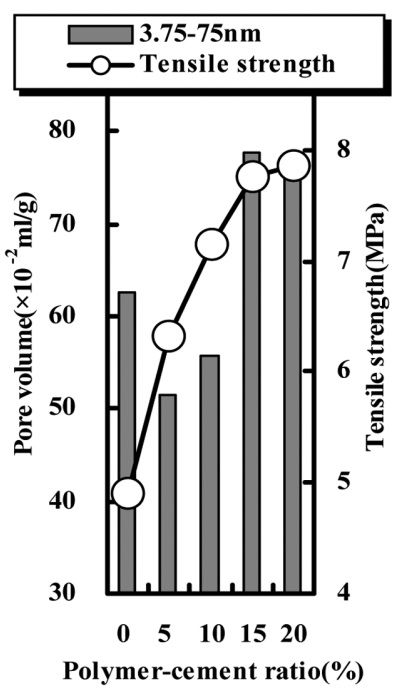

(b) Tensile strength
Figure 10. Polymer-modified mortar using SB60.

에 폴리머 필름이 형성됨으로써 미세공극이 많이 분포하게 되어 강도와 내구성에 영향을 미친다. ${ }^{6}$ 본 연구에서도 폴리머 를 혼입하지 않은 시멘트 모르타르는 부착강도와 인장강도 모두에서 낮은 값을 나타내고 있으며 폴리머를 혼입한 경우 에는 폴리머 시멘트 비가 증가할수록 우수한 값을 나타내고 있다. 폴리머를 혼입하지 않은 시멘트 모르타르의 미세공극 량은 높게 나타나고 있지만 큰 공극량도 높아 전체적인 세공 용적이 증가하여 부착강도나 인장강도를 저하시키고 있다. 반 면에 폴리머를 혼입한 $\mathrm{PCM}$ 에서는 미세공극량의 증가와 전 세공용적이 감소하면서 부착강도 및 인장강도를 증진시키는 것을 알 수 있다. 폴리머 시멘트 비가 증가할수록 폴리머의 형성률이 높아지면서 큰 공극은 줄어들고 미세공극량이 증가 하게 된다. 폴리머 혼입률이 $15 \%$ 일 때 미세공극량이 가장 높 게 나타나고 있고, 부착강도와 인장강도는 $15 \%$ 와 $20 \%$ 에서 유사한 결과를 나타내고 있다.

\section{결 론}

본 연구에서 제조된 $\mathrm{St} / \mathrm{BA}$ 폴리머 필름은 $\mathrm{St}$ 의 함유량이 높을수록 인장강도는 크게 나타나고 신장률은 낮게 나타났다. 연구 결과, 폴리머를 혼입하지 않은 시멘트 모르타르에 비해 부착강도는 최고 3 배 정도, 인장강도에서는 1.6 배 정도의 증 진효과가 나타났다. 폴리머 필름의 인장강도에 따른 폴리머 시멘트 모르타르의 부착강도와 인장특성에서는 $\mathrm{St} / \mathrm{BA}$ 의 단 량체 비가 $60: 60$ 일 때 $60 \%$ 와 $20 \%$ 정도 높은 강도 특성을 나 타내고 있다. 따라서 폴리머 필름의 인장강도를 증진시킨다 면 폴리머 시멘트 모르타르의 부착성과 인장력을 높일 수 있 을 것으로 판단된다. $\mathrm{St} / \mathrm{BA}$ 를 혼입한 폴리머 시멘트 모르타 
르의 세공구조는 $\mathrm{St} / \mathrm{BA}$ 의 단량체 비가 $50: 50$ 과 $60: 40$ 일 때, 폴 리머 시멘트 비가 $15 \%$ 와 $20 \%$ 일 때 미세공극량이 증가하고 폴리머 필름의 형성률이 높아짐에 따라 부착강도와 인장강도 가 증가되는 것으로 나타났다. 본 연구결과를 종합하면 폴리 머 시멘트 모르타르의 부착강도와 인장강도를 증진시키기 위 해서는 폴리머 필름의 인장강도가 높은 폴리머를 시멘트 모 르타르에 $15 \sim 20 \%$ 정도 혼입하는 것이 최적 배합임을 알 수 있다.

감사의 글: 이 연구는 2012학년도 영남대학교 학술연구조 성비에 의한 것임.

\section{참 고 문 헌}

1. W. G. Hyung, K. J. Mun, and W. K. Kim, J. Appl. Polym. Sci., 103, 3010 (2007).

2. W. G. Hyung and Y. K. Jo, Polymer(Korea), 37, 148 (2012).

3. C. Satish, H. Justnes, and Y. Ohama, "Cement Polymer Composite", in Polymer Materials Encyclopedia, Vol 2C, pp. 1389-1402 (1996).

4. Y. Ohama, Handbook of Polymer-Modified Concrete and Martar, Properties and Process Technology, Noyes Publications, New York, 1995.

5. Y. W. Mai and B. Cotterell, Cem. Concr. Res., 16, 646 (1986).

6. A. Shirai and Y. Ohama, Polymers in Concrete, 4, 321 (1998). 